Stipe Grgas

University of Zagreb

\title{
What Has Changed in Nature and in the Economy?
}

The author begins this article by describing the changed priorities of the present: whereas previously attention was focused on social issues, today it is the environment that has become the focus of human concerns. Although the impact of human actions on nature has been noted in the past, the author argues that today this impact is unprecedented. This can be seen, for example, in the way that contemporary engagements with the archive foreground the ecological issue. The author illustrates his disagreement with this practice by glancing at ecologically-minded re-readings of Karl Marx. Turning to American Studies as the disciplinary background of his argument, the author explains the reasons for this focus on Marx. The next step of the paper explores the ecological presence in American Studies before the conclusion, in which the author engages certain works of fiction and shows how he had previously not given sufficient weight to the ecological problematic.

Key words: nature, economy, ecology, Karl Marx, American Studies, negativity

The message was: disorder always won in the end. The idea that man could order the world to his own design was the most pitiful fairy tale ever told.

(Rich 236-37)

One of the transformations that I will be addressing can be formulated with a conditional: if, in the not so distant past, it was possible to address nature and the economy as separate yet related domains, this is no longer the case. If the economy has always been conceptualized as a sphere of human 
existence characterized by dynamics and change, nature, for the most part, was viewed as relatively stable, too big and too (in)different to be affected by human activities. Or so it seemed, until, starting a few decades back, more and more parameters have forced us to attend to the interaction between nature and the economy in a way that puts to question the fundamentals of both categories. To put it in a nutshell: ecological considerations, to name the issue which inevitably surfaces when speaking about nature and the economy today, have insinuated themselves into our thinking about the human and non-human world with an urgency which baffles established paradigms of understanding and explanation. By way of an introduction, I will say a few words about this urgency, how it manifests itself, and how it puts to naught thinking that always seeks historical precedents in coping with what is new.

I strongly disagree with readings of the present that simply see it as more of the same, that downplay the differences the present shows in comparison with conditions of the past. I agree with those who, like Arran E. Gare in the following passage, point to a condition which taxes not only our epistemological capacities but also our habitual ways of living:

Once analyses of postmodernity and modernity are conjoined with analyses of the roots of the global environmental crisis, it will become clear that what we are facing is a unique historical event. In the middle of the nineteenth century, Karl Marx argued that 'only rarely and under quite special conditions is a society able to adopt a critical attitude towards itself'. The situation we are in is one of those quite special conditions in which not merely a society but the whole of modern civilization is being forced to adopt a critical attitude towards itself, a critical attitude even more profound than the critique by Marx of capitalism in the nineteenth century. (2)

Although, to paraphrase Marx, I argue that our society has not adopted a sufficiently critical attitude toward itself, I will also show that Marx in relation to this problematic does not provide that much help. I point this out to distance myself from what I judge are too facile political responses. The 
transformation is such that we cannot rely upon these. On the level of scholarly deliberation - and it would be pretentious to think that we are doing anything more - the environmental crisis forces our strategies of knowledge to refocus the object that we deem as worthy of study and to reappraise the thinkers whose thinking we hold to be relevant.

The three words that set the guidelines for the occasion where the following was delivered - transformation, nature, and economy - could not fail to bring to mind the title of Karl Polanyi's master work The Great Transformation. Polany's exploration of capitalism and his diagnosis of the subordination of social relations to the market are well known. Although many of his prognostications have proven wrong, his insights regarding the absolutism of the economy in today's world are to the point and deserve our attention. In this new absolutism, the economy seems to be totally disembedded from social concerns. As Polany wrote: "To allow the market mechanism to be the sole director of the fate of human beings and their natural environment ... would result in the demolition of society .... Nature would be reduced to its elements, neighborhoods and landscapes defiled, rivers polluted, military safety jeopardized, the power to produce food and raw materials destroyed" (60). On the basis of this passage, it is obvious that Polany was aware of the impact the logic of the market had on the environment although overall he prioritized the societal cost. The transformation I discuss here upturns this hierarchy.

Some thirty years ago, Thomas Wägenbaur, in an essay titled "The Construction of Nature: A Critique of Ecological Reason," diagnosed the change as follows:

Since the beginning of the Seventies nature has replaced society as the referent for critical discourse. With the decline of Marxism nature and not the impoverishment of the proletarian masses became the focus of critical attention. Every discourse, from advertisement to politics, from nuclear energy to 
organically-grown produce appropriated nature as a paradigm. The truth of ecology became the ruling doctrine. (224)

Concerning the degradation of nature, Henri Lefebvre in The Production of Space, a book whose title references both nature and the economy, wrote,

But today nature is drawing away from us, to say the very least. It is becoming impossible to escape the notion that nature is being murdered by 'anti-nature' - by abstraction, by signs and images, by discourse, as also by labour and its products. Along with God, nature is dying. 'Humanity' is killing both of them - and perhaps committing suicide into the bargain. (70-71)

To the point of my argument, the geographer Mike Hulme holds that the relationship between climate and society, in place throughout history and prehistory, "has now taken a more intimate turn. Human actions, globally aggregated, are changing the composition of the atmosphere, which alters the functioning of the climate system. Future climates will not be like past climates" ("Geographical Work"). These three pronouncements illustrate how priorities have changed. In all of them there is a sense of urgency and foreboding that I share.

\section{Is There a Consensus?}

Doing justice to the issue one must acknowledge that there are those who are skeptical about the impact of human action on the planet. Thus Peter Branner, in his The Atlantic article entitled "The Anthropocene is a Joke," calls into question the whole notion of the Anthropocene: "On ecological timescales, human civilization is an event, not an epoch" (Branner). With this distinction, Branner is accusing human thought of nearsightedness, of being unable to see the broader temporal context. However, if that context is extended to the length Branner does in the article, there is hardly anything that can be said about the human condition per se. It dwindles into insignificance. I will 
merely add that the author, by using the word "event," unwittingly assigns significance to human actions because events as such designate a turning point, a happening after which things are not the same. Jan Zalasiewicz, professor of geography at the University of Leicester, is not in a joking mood when, in the summary statement of the "Working Group on the Anthropocene," he contends that if one looks at the main parameters of the "Earth-system metabolism," things started changing dramatically with industrialization (Zalasiewicz). An article in the journal Nature written by Anthony D. Barnosky and others begins with the following contention: "Humans now dominate Earth, changing it in ways that threaten its ability to sustain us and other species. This realization has led to a growing interest in forecasting biological responses on all scales from local to global" (Barnosky et al. 52). The scientists in Nature write of a "global-scale state shift." With a backward glance at the long-scale time of the earth, they state, "Today conditions are very different because global-scale forcings including (but not limited to) climate change have emerged as a direct result of human activities" (Barnosky et al. 54). When they speak of "anthropogenic forcings" and when in their conclusion they suggest strategies to postpone cataclysmic effects, it goes without saying that these activities can be subsumed under the rubric of the economy.

In his book The Entropy of Capitalism (2011), Robert Biel offers an interesting explanation of the relation between the economy and nature which can be used to put the state of the present in perspective. Biel writes that, in the nineteenth and even during most of the twentieth century, it was possible to neglect the damage done to the environment or it could be mitigated through legislation. His explanation accords with what has been said so far:

The social contradictions were thus the most obvious, but even in this case, their intensity was underestimated because they could be exported into the physical environment, through 'growth'. In this sense, there was a 'sequestered' form of ecological decay, itself in a sense a transmuted form of so- 
cial contradiction, which is now exacting its payback in the form of climate change, massive hazard in the food system etc. All of this is, in a way, a result of capitalist society turning its back on the only free resource: the interaction between the natural world and human capacity. (35)

Of particular interest is the notion that societal problems could be "exported" into the environment. Essentially, this is what economic activity does. Biel generalizes by contending that this has been the "escape route" for capitalism: when the social sphere gets too unmanageable, the economy simply increases ecological degradation to compensate for this shortcoming. In the next sentence, Biel diagnoses what today has gone wrong in that relation: "But crucially, this escape route is today much less open than at any time in the past" (161).

It needs to be said that economists who work outside the framework of the mainstream economic paradigm have noted the imbrication of the economy and nature and how both of these entities exemplify what Biel designates as entropic processes. The accusations leveled at mainstream economics point to the assumptions of its logic, which as a rule does not acknowledge the detrimental impact of human activity on the surrounding world. This is the bottom line of the essays assembled in the "Economics and the Ecosystem" issue of the journal Real-World Economics Review (March 19, 2019). In their introduction, Jamie Morgan and Edward Fullbrook warn that "humanity may be sleepwalking toward catastrophe" but that the "very form and function of our political economies resists recognizing the seriousness of the situation":

we have been socialized to conflate larger economies with necessarily better economies and to consider expansionary economies as a predicate of technological solutions to induced problems of economic activity. At the same time, we have been discouraged from thinking about the basic incompatibility of an ever-expanding material economy within a finite world. (3-4) 
The mantras of "growthism" prevent us from recognizing that incompatibility and reduce nature to a mere resource; economic formulas model it as forever subservient and available to human enterprise. If, as Edward Fullbrook writes, "in the 19th century, when today's mainstream economics was invented, the global economy was too small to have observable effects on the ecosphere and none were anticipated" (33-34), things have hugely changed and evidence of this change is all too observable.

\section{Singularity of the Transformation and the Archive}

These remarks suffice to indicate that the ongoing transformation of the relation between nature and the economy is a singular event, in the sense I used the word event above. The sheer size and expanse of the contemporary economy dwarfs the economies of the past. Growth has come with a cost. Therefore, Andreas Malm's remark in his influential book Fossil Capital that there were "sporadic forebodings" (3) of possible fallouts of the industrial revolution in the literature of the time needs to be amended. Today, these forebodings are far from sporadic. They have become the rule. As Steve Rayner in his foreword to Mike Hulme's book Why We Disagree about Climate Change writes,

Climate is more than just a coercive resource to be mobilized behind differ-
ent visions of humanity and its future. It has become the key narrative within
which political issues from the local to the global are framed. In that sense,
debate around climate has succeeded debate around capital and social class
as the organizing theme of political discourse in contemporary society. (xxiii)

Below I will tangentially touch upon the politics that I see ensuing from the acknowledgement that climate has become the key narrative of our times. Before doing so, I will show how that narrative impacts upon the discourses and scholarly formations within which I have chosen to discuss the transformation. 
One of the ways that impact manifests itself is in the practice of rereading the archive for warning signs. By reframing extant texts into the environmental problematic, these texts are made to yield content that in previous readings might have gone unnoticed. It turns out that ecological/climate issues are to be found in the unlikeliest of places. Thus, when Mike Hulme gives, as he writes, a "genealogy of climate change," he points out that Aristotle's student Theophrastus in the third century B.C. "first observed and documented local changes in climate induced by human agency" (Why We Disagree 37). I will not follow up on Hulme's observation by searching for other figures who were conscious of the human-nature relation. I will illustrate this practice of rereading in the case of Karl Marx. I do so not because, as will be shown, I think an ecological rereading of his work is particularly convincing but because I think his thinking on capital is still relevant. Having said that, I think Marx's analysis was, as Edward Fullbrook contends, attuned to the nineteenth century and that he could not have anticipated the effects the economy would have on the ecosphere in subsequent time.

Robert Biel in his book offhandedly remarks that "Marx based his theory on the contradiction between capitalism and nature" (152). Although there is no doubt that this theoretical context helps Biel to chart the "entropies" of capitalism, he does not dwell in depth on Marx and ecology. To show how Marx has been reread as an ecologically minded thinker, we have to go elsewhere. One of the most-cited sources to espouse such a focus on Marx is John Bellamy Foster's study Marx's Ecology: Materialism and Nature (2000). Early in his argument, Foster quotes geographer Massimo Quaini, who wrote, "Marx denounced the spoliation of nature before a modern bourgeois ecological conscience was born" (qtd. in Foster 9). Foster contends that Marx from his earliest years "analyzed the human alienation from nature in a sophisticated and ecologically sensitive form" (20). However, Foster is aware of other readings of Marx which contradict these evaluations. He quotes ecologist John Clark: "Marx's Promethean ... 'man' is a being who is not at home in nature, who does not see the earth as the 'household' of ecology. He is an 
indomitable spirit who must subject nature in his quest for self-realization" (qtd. in Foster 134). Clark's observations are nearer to my own understanding of Marx than those who ecologize him.

Marx employed the concept of metabolism (Stoffwechsel) to define the labor process as a process between man and nature. Foster adds, "Yet an 'irreparable rift' had emerged in this metabolism as a result of capitalist relations of production and the antagonistic separation of town and country" (141). This is a position shared by all who build upon Marx's insight and who blame capitalism for its impact on the environment. This critique of capitalism is valid, but what many of those who adhere to it fail to see is that the order of real existing socialism and the revolutionary project it was a part of are no less to blame for their treatment of nature. I disagree with those who seek to claim Marx for the ecological cause. Ecology was not a top agenda issue in Marxist thought. Let me illustrate this with local evidence. In the 1983 Marx symposium in Dubrovnik, where philosophers debated the relevance of Marx in the then contemporary world, the ecological question was absent excepting its mention in the contribution by the Serbian philosopher Mihailo Marković, who contended that Marx's critique

is inadequate in so far as it does not take into account a natural barrier to ongoing capitalist expansion. An exponential growth of consumption of the earth's resources and of pollution of natural environment is not possible beyond a certain limit to which we quickly approach. This ecological argument which is so important today was not present in Marx's critique. (Petrović and Schmied-Kowarzik 36)

I find this to be a convincing evaluation. Marković was not constrained by dogmatic interpretations of Marx and thus his reading has a particular weight and points clearly to the datedness of Marx's analysis.

Let me add circumstantial proof for this contention. Marx could not have been farsighted enough to foresee the changes that were in store for the 
emergent economic system, let alone its impact on nature. One has to keep in mind that he gleaned his evidence from available sources. Thus, it is worthwhile recalling that one of these was the news magazine The Economist. Although I am not going to reread the archive of The Economist, it is fair to say that ecological concerns were not in the forefront of its attention. But, in retrospect, and in accord with my argument, it is evident that the environment and the climate have, in recent years, figured more and more in its coverage. It is indicative that the September 2019 of the journal (September 21-27, 2019) published a "climate issue" featuring a cover that visually represented the world's average annual temperatures since the mid-nineteenth century. In the lead article, we read that this span of time

saw world wars, technological innovation, trade on an unprecedented scale and a staggering creation of wealth. But those complex histories and the simplifying stripes share a common cause. The changing climate of the planet and the remarkable growth in human numbers and riches both stem from the combustion of billions of tones of fossil fuel to produce industrial power, electricity, transport, heating and, more recently, computation. ("The Climate Issue")

I cite The Economist to show that the issue we are dealing with has seeped down into a journal which hardly questions today's economic order.

\section{Into American Studies}

I have touched upon Marx's ecology because, in a roundabout way, it has a bearing on American Studies. Summarily stated, particularly as Michael Denning (1986) explained, Marxism can be viewed as the enabling other of American Studies. One can go so far as to say that American Studies as a scholarly practice was constituted and developed as an antipode to Marxism. What strikes me in that relation is that the two systems, which vied during the second part of the twentieth century, shared an ecological unconcern. Clive 


\section{Spash and Tone Smith write,}

A long-running claim amongst mainstream economists, defenders of unregulated capitalism and those favoring a regulated productivist economy has been that human ingenuity can find substitutes for all resources and technology can solve all problems allowing humanity to change and adapt to anything. These arguments are made in almost total ignorance of how the economy interacts with ecosystems and impacts their structure and functioning, how dependent economies are on the flow of low entropy materials and energy and what are the basic limits to humans as biological animals. Indeed even ignorance itself is ignored and reduced down to risk and probabilities. (212)

Little needs to be added to this pronouncement. To reiterate: the project of American Studies was conceived as an identitarian project opposing the cultural work of the Soviet system. As such, it reiterated values and realities which differentiated the United States from the rest of the world. It is indicative that environmental issues did not figure prominently in its self-conceptions, that it shared an unconcern regarding the devastation of nature with its enabling other. An explanation of this convergence is to be found in the ideology of growth and development shared by both world systems. In other words, both systems espoused the same metabolism when it came to the man-nature relationship.

Keeping this in mind, it comes as no surprise that, in the strict sense of the word, environmental concerns have not figured very prominently in the American Studies tradition. In his review article "Necrocracy in America," Mathew Schneider-Meyerson contends that American Studies has for the most part ignored "climate change and the still-accelerating consumption of fossil fuels despite our awareness of the catastrophic environmental and human consequences" (530). This is a grave fault, considering, as he writes, that "Future historians may remember the United States in the twentieth and early twenty-first centuries principally as the progenitor of the rising seas, extreme weather events, volatile climate, and acidified, littered, oceans that 
plague their times" (529). In his notes, he writes that The Journal of American Studies and The Journal of Transnational American Studies have paid the most attention to energy and climate change. I have perused these journals but have not found a theoretically informed purchase on the ecological issue from the standpoint of American Studies. An exception to this absence of references to the environmental issue in American Studies is Robert S. Levine's article "American Studies in an Age of Extinction," where "global warming" is mentioned in his survey of "visions of the end" in American culture, which, according to Levine, is pervaded by concerns that life on the planet may be coming to an end. Levine writes, "But it is human-induced climate change that has generated the greatest concern about the possibility that the planet will soon be unable to support life" (161). Mathew Schneider-Meyerson and Robert S. Levine work with different archives and reach different conclusions. But if we give the matter some thought, it turns out that the ecological issue is part and parcel of American Studies.

Could it be otherwise, considering the role that land, geography, and nature has played in providing images, metaphors, and narratives constitutive of American identity? Not having much truck with historical duration, the self-projections of the young Republic played themselves out on the seemingly inexhaustible continent. I will add to this that pioneering work in American Studies has customarily downplayed the importance of the economy and business. However, this is too much of a simplification. The economy can be said to make a return synecdochically in at least one of the founding texts, that is, in Leo Marx's metaphor of the machine in the garden. As Marx puts it near the end of his study, "The contrast between the machine and the pastoral ideal dramatizes the great issue of our culture. It is the germ ... of the most final of all generalizations about America" (353). I will return to Leo Marx, but if we recall his argument, it is obvious that his study staged the scene for the transformation that we are now witnessing. I will add that, in a 2008 article, Leo Marx recognized how in the 1970s, "with the onset of the 'ecological crisis', the refurbished, matter-of-fact environment took over a large part of 
the niche in public discourse hitherto occupied by the word nature" (Marx). With the later statement, he makes explicit what was implicitly present in his founding text.

Whether as a part of self-legitimating rhetoric or as an archive of landscapes representing American specificity, nature is a constant motif in American Studies. Whether as a wilderness, a garden, or a continental expanse, external nature provided the stage for the development of the American project. Different readings of the American experience provide a chronology of how those engaged in that project related to nature. That relation, manifested in land proprietorship, in turning nature into ground to be tilled, in using machines to traverse distances in nature, et cetera, gives a chronology of American economic history. Put otherwise, in the United States and earlier in the colonies, nature was always transformed to accommodate the dynamic of economic growth. In one of the founding texts of American studies, "Nature and the National Idea," Perry Miller contended that the American theme was that of Nature versus civilization. In the article, Miller emphasized and gave an explanation of how nature functioned in the American imagination and how it was being endangered by the economic calculus. The function of nature in the discourses he explored was ideological: "The most utilitarian conquest known to history had somehow to be viewed not as inspired by a calculus of rising land values and investments but (despite the orgies of speculation) as an immense exertion of the spirit" (207). America was projected as "Nature's nation," notwithstanding the oxymoronic semantics of the phrase and the economic realities that were bringing the devastation of nature into view.

\section{Politics, Economic Orthodoxy, and Nature Transformed}

If, as Mathew Schneider-Meyerson contends, the United States will be remembered in the future as the "progenitor" of ecological disasters, this will be so because of the success of its "utilitarian conquest." Doing American Studies, we register that unprecedented success but must remember that it 
contributed, more than other societies did, to the transformations of nature we are now witnessing. As Robert Biel formulates this, "it is the ravages of capitalism's past excess which now return to haunt, not just the mode of production itself ... but in a broader sense the future of humanity" (126). Capitalism's excesses are not equally distributed. On the next page of his book, Biel informs us that "China despite being the world's most populous country and even with its recent extremely rapid industrialization, has contributed less than $8 \%$ of the total emissions of carbon dioxide from energy use since 1850, compared with $29 \%$ for the United States." He summarizes:

What this effectively means is that the South suffers twice: first, from the legacy of the destruction exported to it while colonization and neocolonialism were fueling the North's industrial order; secondly, through the payback on the entropy which was then being exported to the future, and now returns as climate change. It should be noted that projections suggest that the effect will be uneven in the opposite sense to the responsibility, i.e. the South which caused less of the problem will suffer more of it: the map of estimated mortality attributable to climate change exactly follows the North-South divide. (127)

If American Studies includes in its agenda the transformation under discussion, it has to acknowledge the disproportionate impact its object of study has had on that transformation. Max Koch is clear about the inequality of rich and poor countries facing the ecological crisis, the case being that rich countries

do not only have the bulk of historical responsibility for the ecological crisis, but also continue to consume an amount of environmental resources that cannot be generalized to the rest of the planet without further crossing planetary boundaries. For these countries especially economic growth as the top policy priority would need to be deprioritized and replaced by biophysical parameters as well as by a general policy orientation on basic needs satisfaction. (99) 
As things stand now, it is difficult to imagine that the deprioritization of growth will figure in either rich or poor countries. Current policies follow a different trajectory and marginalize activism prompted by calls for ecological justice.

In their chronology of the politics of climate change, Nathaniel Rich and George Steinmetz mention Ronald Reagan, who rolled back environmental protection by appointing officials to the Interior Department and the EPA who supported fossil-fuel production and deregulation (Rich and Steinmetz). But Reagan was only following in the steps of Richard Nixon, who had said,

There are only seven per cent of the people in the world living in the United States, and we use thirty percent of all the energy. That isn't bad; that is good. That means we are the richest, strongest people in the world, and that we have the highest standards of living in the world. That is why we need so much energy and may it always be that way. (qtd. in Biel 134)

Let me add to this the famous pronouncement made by George W. H. Bush back in 1992, just before the Earth Summit in Rio de Janeiro: "The American way of life is not up for negotiations. Period” (Deen). The present occupant of the White House would doubtlessly concur with these assessments. While working on this paper, I read an article on 12 January 2020 in the Guardian written by Ross Barkan entitled "Trump has savaged the environment. The planet cannot afford a second term" (Barkan). These pronouncements are relevant for American Studies because they show how entrenched is an economic system that would have to be modified to meet the needs of a nature transformed. I mention this because of the two realities that I have addressed so far - nature and the economy - it is only the economy that can be transformed in order to cope with what it itself has done to nature.

Following up on this, American Studies can explore how environmental issues put to question the activism practitioners of the discipline from 
the United States assign to it. In his article Mathew Schneider-Mayerson writes, "A radically different climate is not simply another issue deserving of concern but a likely catalyst for the kind of massive social and political destabilization that would negate the important cultural, social, and political work American studies has accomplished since its inception" (538-39). I understand the word "destabilization" here to mean the transformation from the socio-political sphere to the current focus on the non-human world. Simply put, questions of racial, class, ethnic, or sexual justice disappear in the face of the apocalypse. We feel helpless in the face of suprahuman forces and processes. Not everybody agrees with this diagnosis. In an interview indicatively titled "It is time to try out an 'ecological Leninism," Andreas Malm critiques the notion of the Anthropocene because he wants us to see that not everybody, but only some humans, have caused the mess. He comments, "If the human species is the culprit, there's little we can do about it. If dominant classes and contingent social relations are the problem, then we can attack it at the root" (Malm). But can we?

I have doubts about any kind of ameliorative action. But, needless to say, the revolutionary ethos finds it hard to accept this passivity. The case of Bernard Stiegler is illustrative. In his book The Neganthropocene, Stiegler writes,

Halfway through the second decade of the twenty-first century, we, non-inhuman beings that we are, find ourselves trying to live within a state of emergency that is permanent, universal, and unpredictable, and that seems bound to become unliveable. We all feel this urgency. But most of the time we deny it - except when we have no choice but to observe its immediate and disastrous effects upon our everyday existences, which tend thereby to find themselves reduced to subsistence, that is, to survival. (204)

However, Stiegler's intellectual ethos cannot accept this reduction: "A leap beyond this entropic situation is required, beyond this state of fact, a bifur- 
cation from this chaos that would be capable of opening up a new era, upon which we shall bestow the name, 'Neganthropocene”' (141). Taking into account scientific evidence and the pronouncements of those who are deciding our future, I think this is wishful thinking. I share with Alexander M. Stoner and Andony Melathopolous doubts regarding the capacity of society to self-consciously transform itself. Here is what they say:

While a person like James Watts would have held the aspirations for the free development and transformation of society from the constraints of feudalism - that is, the idea and political project for freedom - our moment is marked by a dramatic attenuation, or even distrust, that such transformation is even desirable. (20)

Corroborating my contention regarding the singularity of the present, I hold that, unlike Watts, I recognize, in agreement with Moishe Postone, "a profound sense of helplessness regarding the capacity of society to self-consciously transform itself in ways that are not predetermined from the outset" (Postone). If, as Erik Swyngedouw reminds us, apocalyptic imaginaries have been with us for a long time, this gives us no comfort because, as he goes on to add, "present-day millennialism preaches an apocalypse without the promise of redemption" (218). The implications for human action are far reaching: "The environmentally apocalyptic future, forever postponed, neither promises redemption nor does it possess a name: it is pure negativity" (219).

In a paradoxical way, a mutation of the economy, namely its financialization, has devised one of the rare procedures for dealing with this negativity. Robert Biel succinctly describes it as the process by which finance capital drags humanity towards disaster "by picking up the signals of crisis and distorting them into positive feedback" (164). This is no place to go into how insurance and finance make a profit out of ecological disasters, but it is evident that what is at stake here is an approach that does not propose transforming 
the economy but applies the logic that got us here in the first place to changed circumstances. The quote at the beginning of my paper comes from Nathaniel Rich's novel Odds Against Tomorrow, which thematizes precisely this issue. The "future-affected anxiety disorder" (51) of the main character, the portrayal of a world that persists in its normalcy until the event which makes this impossible, the images of "a new world we've made" (147) - all these and many other motifs in the novel sketch the world into which we have landed. Rich's novel is a latecomer to a lineage of American writers who, as Leo Marx writes in the epilogue to The Machine in the Garden, "have dwelt upon the contradiction between the rural myth and technological fact" (354). If the writers Marx chose dwelt upon the contradiction between nature and the economy, numerous contemporary writers do not dwell upon the relation but narrate how it has morphed into a no-win situation.

\section{My rereadings}

Richard Powers's last novel, Overstory, upturns our habitual priorities. It focuses upon and narrates a world of trees. Here are two samplings from the opening page of the novel: first, "The several hundred kinds of hawthorn laugh at the single name they're forced to share" (3); and the second, "All the ways you imagine us - bewitched mangroves up on stilts, a nutmeg's inverted spade, gnarled baja elephant trunks, the straight-up missile of sal - are always amputations. Your kind never sees us whole. You miss the half of it, and more. There's always as much below ground as above" (3). Simply put, Powers reveals that human enterprise simplifies the complexity of the earth and brings it "to its rationalized end" (21). Trees fare badly in that end: "Still the Age of Wood. Cheapest priceless stuff that ever has been" (185). For my purpose it is important to note that Powers's ecological novel intermittently gestures to the economic processes transforming nature.

This prompted me to go back to his novel Gain, perhaps the most focused fictional effort to narrate American capitalism, and see whether nature in the earlier novel figures in the description of the economy. Reveal- 
ingly, even trees appeared in the earlier text in asides such as "if somebody needs the trees to get well, to hell with the owl" (Gain, 151) or later in the novel, somewhere on the coast of British Columbia "machines receive these trees" (345). I will list a number of instances in the novel where the author explicitly mentions the relationship between nature and the economy. At the very beginning of the novel, we read that the town of Lacewood "thrived on alchemical transformations. Growth from bone meal and bat guano" (3-4). Concerning the railroad, it is stated that it "plowed into the frontier, as inevitable as the grave to which all expansion leads" (42). Another economic epoch is described as follows: "Life now headed, via a web of steam-cut canals, deep into the interior" (67). Elsewhere, echoes of our theme are to be found: "If Nature were no more than eternal transformation, Man's meet and right pursuit consisted of emulating her" (79). In a rhapsodic delivery on the telegraph, Powers writes, "For how many eons had insurmountable geography impeded man's business? Now the new American race had burst those shackles" (91). Nature references appear in Powers's rendering of economic creative destruction: "The waters had constantly to leave behind the landscape they drained, if ever they meant to reach open sea. So, too, nay forward-looking enterprise had to be ready to cast off what had once been its mainstay" (105-6). The dynamic of advancement and its impact on nature as waste is seen in the following: "Human progress had already taken a considerable toll. The very gas lamps that lifted the pall of night also issued a rising tide of coal tar treacle that threatened to drown the nation in advancement's sewage" (144-45). I add a generalization from the novel: "Commerce aimed at manipulating nature on a truly grand scale" (166). At one point in the diachrony of American capitalism, it is stated that "The earth had become a factory" (198). Nearing the end of the novel, we find explicit references to "global warming" (231) and "ecology" (341). Rereading Gain, I found in Powers references to the problematic which I think is the most pressing issue of the present. In my earlier reading, it was not there (Grgas). The urgency of the environmental issue changed the priorities of my readings. I will conclude on a personal note. 
Namely, in the introduction to the collection of essays The Construction of Nature, Svend Erik Larsen and I wrote the following:

When we nowadays say that nature is in crisis, what we mean is that the boundary between nature and culture has reached a critical point. Nature in itself is not going through a crisis. It can turn into a moorland, be swamped by the sea or freeze into icy wastes, as it has already done during the aeons of terrestrial history. However, nature that human culture is supposed to survive in and have responsibility for the positioning of its boundaries, is being choked to death. (Grgas and Larsen 7-8)

It is only the earlier-mentioned Thomas Wägenbaur, who in his two contributions to our collection explicitly addressed the ecological issues. From the present point of time - to update the deictic "nowadays" of some thirty years ago - I find it strange that the ecological thematic did not figure more promptly at the 1992 Alborg workshop. The above quote from our introduction shows that we were aware of the problem but, in retrospect, it seems not to have been a cause of existential anxiety - it was not "intimate" enough. The detachment which I now recognize in the way we speak of crisis, our blasé attitude, is, as far as I am concerned, no longer a viable position. The nature that is being choked to death nowadays is no longer the nature that we conceptualized from our culture-biased approach. It has become much more visceral, much more intimate.

\section{Works Cited}

Barkan, Ross. "Trump has savaged the environment. The planet cannot afford a second term." The Guardian, www.theguardian.com/commentisfree/2020/jan/17/donaldtrump-environment-epa-climate-second-term. Accessed 30 Jan. 2020.

Barnosky, Anthony D. et al. "Approaching a state shift in Earth's biosphere." Nature, no. 486, 7 June 2012, pp. 52-58. 
Biel, Robert. The Entropy of Capitalism, Brill, 2012.

Branner, Peter. "The Anthropocene is a Joke". The Atlantic, www.theatlantic.com/science/ archive/2019/08/arrogance-anthropocene/595795/. Accessed 25 Jan. 2020.

Deen, Thalif. "U.S. Lifestyle Is Not Up for Negotiation”. Inter Press Service, www.ipsnews. net/2012/05/us-lifestyle-is-not-up-for negotiation. Accessed 2 Jan. 2020.

Denning, Michael. “'The Special American Conditions': Marxism and American Studies.” American Quarterly, vol. 38, no. 3, 1986, pp. 356-80.

“The Climate Issue." The Economist, www.economist.com/leaders/2019/09/19/theclimate-issue. Accessed 15 Jan. 2020.

Foster, John Bellamy. Marx's Ecology. Materialism and Nature, Monthly Review, 2000.

Fullbrook, Edward. "Economics 101: Dog barking, overgrazing and ecological collapse." Real-world economics review, no.87, 2019, pp.33-35, www.paecon.net/PAEReview/ issue87/Fullbrook87.pdf. Accessed 15 Dec. 2019.

Gare, Arran E. Postmodernism and the Environmental Crisis, Routledge, 1995.

Grgas, Stipe. “Tijelo u romanu Richarda Powersa Gain.” [sic]: a journal of literature, culture and literary translation, www.sic-journal.org/ArticleView.aspx?aid=39, no. 1, 2010, doi: 10.15291/sic/1.1.lc.3.

Grgas, Stipe, and Svend Erik Larsen, editors. The Construction of Nature, Odense UP, 1994. Hulme, Mike. "Geographical work at the boundaries of climate change." 2007. Transactions of the Institute of the British Geographers, Academia.edu/32422403/Geographical _work_at_the_boundaries_of_climate_change. Accessed 1 Feb. 2020.

---. Why We Disagree About Climate Change: Understanding Controversy, Inaction and Opportunity, Cambridge UP, 2009.

Koch, Max. "Elements of a political economy of the postgrowth era." Real-world economics review, issue no. 87, 19 March, 2019, pp. 90-105, http://www.paecon.net/

PAEReview/issue87/Koch87.pdf. Accessed 30 Nov. 2019.

Lefebvre, Henri. The Production of Space, Blackwell, 1991.

Levine, Robert S. "American Studies in an Age of Extinction." States of Emergency: The

Object of American Studies, edited by Russ Castronovo and Susan Gillman, The U of North Carolina P, 2009, pp. 161-82.

Malm, Andreas. Fossil Capital: The Rise of Steam Power and the Roots of Global Warming, Verso, 2016. 
---. "It is time to try out an 'ecological Leninism,'” www.versobooks.com/blogs/4450-it-istime-to-try-out-an-ecological-leninism-interview-with-andreas-malm. Accessed 1 Dec. 2019.

Marx, Karl. Capital: Volume I. Translated by Ben Fowkes, Penguin Books, 1990.

Marx, Leo. The Machine in the Garden: Technology and the Pastoral Ideal in America, Oxford UP, 1964.

---. "The Idea of Nature in America”. Daedalus, 2008, http://amacad'org/publication/ideanature-america. Accessed 17 Aug. 2019.

Miller, Perry. "Nature and the National Ego." 1956. Errand Into the Wilderness. The Belknap P, 1993, pp. 204-16.

Morgan, Jamie, and Edward Fullbrook. "Introduction: Economics and civilization in ecological crisis." Real-world economics review, issue no. 87, 19 March 2019, pp.2-8, www.paecon.net/PAEReview/issue87/MorganFullbrook87.pdf. Accessed 10 Oct. 2019.

Petrović, Gajo, and Wolfdietrich Schmied-Kowarzik. Die gegenwärtige Bedeutung des Marxischen Denkens. Marx-Symposion 1983 in Dubrovnik, Germinal Verlag, 1985.

Polanyi, Karl. The Great Transformation, Beacon Press, 1954.

Postone, Moishe. "History and Helplessness: Mass mobilization and Contemporary Forms of Anticapitalism." Public Culture, vol. 18, no. 1, 2006, archive.org/stream/ HistoryHelplessnessMoishePostone/History\%20\%26\%20Helplessness\%20-\%20 Moishe\%20Postone_djvu.txt. Accessed 10 Dec. 2019.

Powers, Richard. Gain, Vintage, 2001.

---. Overstory, W.W. Norton, 2018.

Rayner, Steve. “Foreword." Why We Disagree About Climate Change: Understanding Controversy, Inaction and Opportunity, by Mike Hulme, Cambridge UP, 2009, xxi-xxiv.

Rich, Nathaniel. Odds Against Tomorrow, Farrar, Strauss and Giroux, 2013.

Rich, Nathaniel, and George Steinmetz. "Losing Earth," 2018, pulitzercenter.org/ reporting/loosing-earth-decade-we-almost-stopped-climate-change Accessed 15 Jan. 2020.

Schneider-Mayerson, Mathew. "Necrocracy in America: American Studies Begins to Address Fossil Fuels and Climate Change." American Quarterly, vol. 67, no. 2, 2015, 
pp. 529-40.

Spash, Clive L., and Tone Smith. "Of ecosystems and economies: re-connecting economics with reality." Real-world economics review, issue no. 87, 19 March 2019, pp. 212-29, www.paecon.net/PAEReview/issue87/SpashSmith87.pdf. Accessed 15 Nov. 2019.

Stiegler, Bernard. The Neganthropocene, Open Humanities P, 2018.

Stoner, Alexander M., and Andony Melathopoulos. Freedom in the Anthropocene: TwentiethCentury Helplessness in the Face of Climate Change, Palgrave, 2015.

Swyngedouw, Erik. "Apocalpse forever? Post-political populism and the spectre of climate change." Theory, Culture and Society, vol. 27, 2010, pp. 213-32.

Wägenbaur, Thomas. “The Construction of Nature: A Critique of Ecological Reason.” The Construction of Nature, edited by Stipe Grgas and Svend Erik Larsen, Odense UP, 1994, pp. 224-49.

Zalasiewicz, Jan, et al. “The Working Group on the Anthropocene: Summary of evidence and interim recommendations." Anthropocene, vol. 19, 2017, pp. 55-60, www. researchgate.net/publication/319613362_The_Working_Group_on_the _ Anthropocene_Summary_of_evidence_and_interim_recommendations, doi: 10.1016/j.ancene.2017.09.001. Accessed 3 Feb. 2020. 